IBAD Sosyal Bilimler Dergisi

IBAD Journal of Social Sciences

dergipark.org.tr/ibad

IBAD, 2021; (10): 442-461

DOI: $10.21733 / \mathrm{ibad} .882763$

Özgün Araştırma / Original Article

\title{
Ortaokullarda Görev Yapan Öğretmenlerin Örgütsel Güven Algıları
}

\section{Organizational Trust Perceptions of Teachers Working in Secondary Schools}

\author{
Burak Karakuş \\ Soner Doğan ${ }^{2 *}$ \\ * Sorumlu yazar \\ Corresponding author
}

${ }^{1}$ Öğretmen, Milli Eğitim Bakanlığı, Türkiye,

Teacher, Ministry of Education, Turkey

brk_58@hotmail.com

ORCID ID 0000-0001-9140-5477

${ }^{2}$ Doç. Dr., Sivas Cumhuriyet Üniversitesi, Türkiye,

Assoc. Prof. Dr., Sivas Cumhuriyet University, Turkey,

snr312@gmail.com

ORCID ID 0000-0003-2013-3348

Makale geliş tarihi / First received : 18.02.2021

Makale kabul tarihi / Accepted : 07.04.2021

Bilgilendirme / Acknowledgement:

1- Yazarlar tez yazım sürecinde ve tezin makaleye dönüştürülme sürecinde ortak bir çalışma yürütmüştür. Makalenin dergiye sunumu, takip edilmesi ve sonlandırılması sürecini ikinci yazar yapmıştır.

2- Makale tezden üretilmiştir.

3- Araştırmaya katılan öğretmenlere teşekkür ederiz.

4- Makalenin yazarları arasında çıkar çatışması bulunmamaktadır.

5- Makale 2019 yılında tamamlanan bir yüksek lisans tezinden üretilmiştir. İlgili yüksek lisans tezinde ölçeğin uygulama izni 10.01.2019 tarihli ve 92255297-604.01.01-E. 661627 sayılı valilik onayı ile alınmıştır.

6- Bu makalede araştırma ve yayın etiğine uyulmuştur.

This article was checked by iThenticate. Similarity Index $14 \%$

\section{Atıf bilgisi / Citation}

Karakuş, B. ve Doğan, S. (2021). Ortaokulda görev yapan öğretmenlerin örgütsel güven algıları. IBAD Sosyal Bilimler Dergisi, (10), 442-461. 
ÖZ

$\mathrm{Bu}$ araştırmada, ortaokullarda görev yapan öğretmenlerin çeşitli değişkenlere göre örgütsel güvene ilişkin algılarını nın değerlendirilmesi amaçlanmıştır. Tarama modeline göre desenlenen araştırmanın çalışma grubunu 2018-2019 eğitim-öğretim yılında Sivas il merkezindeki 14 ortaokulda görev yapan 278 öğretmenin tamamı oluşturmaktadır. Araştırmada veri toplama aracı olarak “Örgütsel Güven Ölçeği” kullanılmıştır. Veriler SPSS 18 programı kullanılarak analiz edilmiştir. Araştırma bulgularına göre ortaokulda görev yapan öğretmenleri örgütsel güvene ilişkin genel algısı yüksek düzeydedir. Alt boyutlar bazında incelendiğinde ise paydaşlara güven boyutu hariç (orta düzey) diğer alt boyutlardaki örgütsel güven puanlarının yüksek düzeyde olduğu saptanmıştır. Cinsiyet, yaş, meslekteki hizmet süresi ve okuldaki hizmet süresi değişkenlerine göre ortaokul öğretmenlerinin görev yapılan okullarının örgütsel güvene ilişkin algılarında anlamlı bir farklılığın olduğu sonucu ortaya çıkmıştır. Öğretmenlerin çalışma ortamlarında örgütsel güven algilarını olumlu yönde geliştirmek amaciyla okul ortamında öğretmenlerin daha çok etkileşime girebilecekleri, toplantılar, sosyal ve kültürel faaliyetler gibi organizasyonların hayata geçirilmesi önerilebilir.

\section{Anahtar Kelimeler}

Güven, örgütsel güven, ortaokul öğretmenleri

\section{ABSTRACT}

In this research, it is aimed to evaluate the perceptions of teachers working in secondary schools regarding organizational trust according to various variables. The study group of the research, which is patterned according to the screening model, is made up of all 278 teachers working in 14 secondary schools in Sivas city center in the 2018-2019 Academic Year. In the research, the "Organizational Trust Scale" was used as a data collection tool. The data were analyzed using SPSS 18 program. According to the research findings, the general perception of organizational trust of teachers working in secondary school is high. When examined on the basis of subdimensions, it was found that organizational trust scores in other sub-dimensions were high, except for the trust dimension to stakeholders (mid-level). It has been detected that there is a significant difference in the perceptions of the secondary school teachers regarding organizational trust of the schools where they work, according to gender, age, duration of service in the profession and duration of service in the school. In conclusion, it may be proposed to organize events like meetings, social and cultural activities where teachers can interact more in the school environment, in order to positively improve teachers' perceptions of organizational trust in their working environments.

\section{Keywords}

Trust, organizational trust, secondary school teachers 


\section{GİRIŞ}

Bireyin bulunduğu çevrede yer alan diğer bireylerle kurulan ilişkilerin niteliğinde ve belirlenen ortak hedefi gerçekleştirme amacıyla insanların bir araya gelerek kurdukları örgütlerin varlığını sürdürmesinde önemli bir etken olan güven, günümüzde de sosyal bilimler alanında birçok araştırmaya konu olarak yaşamamızda önemli bir kavram haline gelmiştir. İnsan için en temel duygu olan güven, insanın yaşantısının her anında yer alır (İnam, 2003). Sosyal bir varlık olan insanı anlamlandırma bağlamında güven kavramı anahtar bir rol üstlenmektedir (Gibb, 1991). Bireylerin, ilk topluluklardan bugüne kadar yaşamlarını sürdürmelerinde ve birbirlerine destek olmalarında güven faktörü bir ihtiyaç olarak görülmektedir. İçinde bulunduğu toplumda ortak bir değer olan güven, bireyleri yapıcı ilişkilere yönlendirmekte ve iyi toplumun oluşmasına destek vermektedir (TschannenMoran ve Hoy, 2000).

Güven kavramına atfedilen bu önem, sosyal bilimlerden başta psikoloji ve sosyoloji olmak üzere daha birçok disiplinlerin araştırma konusu olmasını sağlamaktadır. Bu durum her disiplinin kendisine özgü güven tanımlamaları, konu ile ilgili farklı genellemeler ve değerlendirmeler imkânı doğmuştur (Hosmer, 1995; Kalemci Tüzün, 2007). Güven ile ilgili ortaya çıkan bu durumun bireylerde bir belirsizliğe sebep olsa dahi hem bireysel hem de örgütsel yaşamda önemli bir ihtiyaç olarak görülmesi bakımından bilim insanları arasında uzlaşma olduğu görülmektedir. Kuşkusuz insan davranışlarında en büyük etkiyi oluşturan güven kavramı, içinde yaşanılan çevredeki insan ilişkilerin temelini oluşturduğu söylenebilir. Buna ek olarak insanlar arası ilişkilerde belirsizliği ortadan kaldırmak için güven bir aracıdır (Asunakutlu, 2002; Polat, 2009; Tokgöz ve Seymen, 2013; Gezen ve Boz, 2013; Arslan, 2018).

Her disiplinin, güvenin bireysel, örgütsel ve toplumsal rolünü farklı bakış açıları ile açıklamaya çalışması tanımını da zorlaştırmış çok farklı tanımların ortaya çıkmasına sebep olmuştur (Fettahlıoğlu ve Sayın, 2015; Seçilmiş ve Kılıç, 2017). Literatürde birçok alana konu olmuş güven kavramına dair farklı tanımlamalara rastlanmaktadır. Güven kavramının temelinde dürüstlük, yeterlilik (veya yetenek) ve yardımseverlik olduğunu vurgulayan Mayer ve arkadaşları (1995) güveni; bireyler arası karşılıklı ilişkilerde bir kişinin diğerinin eylemine karşı gösterdiği savunmasızlık hali olarak tanımlamıştır (Mayer, Davıs ve Schoorman, 1995).

Güven kavramının içerisinde risk barındırdığını belirten Erdem (2003) güven kavramının doğasında belirsizliğin, sonuçlarında olumlu ve olumsuz yaşantıların olabileceğine vurgu yapmıştır. Öte yandan İşcan ve Sayın (2010) ise güveni, tarafların birbirleri hakkında zarardan ziyade yarar göreceği yönünde beklenti içinde olmaları bağlamında değerlendirmiştir. Erdem, (2003), İşcan ve Sayın, (2010) ifadelerinden yola çıkarak güvenin bireylerin çabaları doğrultusunda kazanılması gereken bir süreç olduğu, güven kazanılmış olsada bazen kazanılan güvenin karşı tarafa zarar vermek amacıyla kullanılabileceği söylenebilir. Bu bağlamda güven kazanma sürecinin iyi bir şekilde tahlil edilmesinin, ortaya çıkabilecek sonuçlardan olumlu kazanım elde etme konusunda faydalı olacağı sonucuna ulaşılabilir.

Bireysel güven ile örgütsel güvenin benzer yönleri olsa da genel olarak birbirinden farklıdır. $\mathrm{Bu}$ konu üzerinde araştırma yapan bilim insanları, güvenin olumlu gelişen kişilerarası 
ilişkilerinde önemli bir unsur olarak; güvenin örgüt açısından önemini belirlemişlerdir (Tan ve Tan, 2000). Günümüzün şartlarının getirdiği teknolojik ve diğer yenilikler karşısında devamlılıklarını sürdürmelerinde, ileriye dönük belirlediği hedefleri gerçekleştirmede ve vizyon oluşturmasında örgütsel güven vazgeçilmez bir unsurdur (Halıcl, Söyük ve Gün, 2015; İbrahimoğlu, Yaşar ve Kızıloğlu, 2011; Candan, 2014). Örgütsel güven Brehrn ve Gates (2002) göre örgüt içerisinde başarıyı sağlayan önemli bir faktördür. Ayrıca bilim insanlarının bir çoğu örgütsel güvenin; bireysel performans ve motivasyonu artırma, iş tatminini sağlama, örgütsel vatandaşlık kazandırma, örgütsel bağlılığı geliştirme, problem çözme becerilerini kazandırma, işten ayrılma eğilimini azaltma vb. konular üzerinde pozitif etkisinin olduğunu belirtmektedir (Thomas, Zolin ve Hartman, 2009).

Örgütsel güven kavramı literatürde farklı boyutlarda araştırma konusu olarak incelenmiştir. Polat, (2007) örgütsel güvenin, yöneticiye güven ve örgüte güven şeklinde iki boyutunun olduğunu ileri sürerken örgütsel güven konusunda yapılan diğer birçok araştırmalarda ise örgütsel güvenin boyutları olarak: örgüte güven, amire/yöneticiye güven ve iş arkadaşlarına (meslektaşlarına-çalışanlara) güven öne çıkmıştır. Araştırmacıların örgütsel güveni oluşturan bu boyutların birbiriyle ilişkili ve birbirlerini tamamlar nitelikte olduğu konusunda görüş birliği içerisinde oldukları görülmüş̧tür (Tan ve Tan, 2000; Güler, 2014; Halıcı, Söyük ve Gün, 2015; Korkmaz, 2017; Paşa ve Işık, 2017; Seçilmiş ve Kılıç, 2017; Kars, ve İnandı, 2018; Arslan, 2018).

İnsan ilişkilerinin yoğun olarak yaşandığı yerlerden birisi de eğitim örgütü olan okullardır. Okulların temel amacı öğrencilere ilgi ve kabiliyetlerini gerçekleştireceği bilgi, beceri ve olumlu davranışlar kazandırarak onları hayata hazırlamak, kendilerini mutlu edecek ve toplumun refahına katkı sağlayacağı bir meslek sahibi olmalarını sağlamaktır. Bu bağlamda toplumların gelişiminde birinci derecede etkili olan okulların güvenin en üst düzeyde hissedildiği yerler olması gerekmektedir. Güven faktörünün okulların belirledikleri hedefler sonucunda elde ettikleri başarıların kazanılmasında ve okulların kurumsal bir kimlik oluşturmasına katkı sağlayacağı söylenebilir.

Okul ortamında güven kaynaklı ortaya çıabilecek bir sorun öğrencilerin davranışına, tutumuna ve akademik başarısına olumsuz yönde bir etkisi olabilmektedir. Bunun yanında, güvenin hakim olduğu okullarda görev yapan öğretmenler kendini daha rahat ifade eder ve karar alma sürecinde yer alarak okul tarafından belirlenen hedeflerin gerçekleştirilmesinde daha etkin olacaklardır. Literatür incelemesi yapıldığında eğitim örgütlerinde örgütsel güven konusuna ilişkin araştırmalara rastlanmaktadır. Bu araştırmalar çoğunlukla örgütsel güven kavramını bir başka kavramla ilişkilendirmek üzerine yapılandırılmıştır.

Örneğin; Hoy ve Tarter (2004) okullarda örgütsel adalet ve örgütsel güven düzeyleri arasındaki ilişkiyi, Smith ve Birney (2005) ilkokullarda öğrenci zorbalığı ve örgütsel güveni, Hodge ve Ozağ (2007) öğretmenlerin örgütsel güven, umut ve örgütsel bağlllık değişkenleri arasındaki ilişkiyi, Polat ve Celep (2008) öğretmenlerin örgütsel adalet, örgütsel güven ve örgütsel vatandaşlık davranışları değişkenleri arasındaki ilişkiyi, Yücel ve Samancı (2009) ilköğretim okulu öğretmenlerinin görüşlerine göre, ilköğretim okullarındaki örgütsel güven ve örgütsel vatandaşlık davranışı arasındaki ilişkiyi, Cerit (2009) sınıf öğretmenlerinin örgütsel güven düzeyleri ve işbirliği yapma düzeyleri arasındaki ilişkiyi, Baş ve Şentürk (2011) ilköğretim okulu öğretmenlerinin örgütsel adalet, örgütsel vatandaşlık ve örgütsel güven 
algılarını, Cemaloğlu ve Kılınç (2012) okul müdürlerinin liderlik stilleri ile öğretmenlerin örgütsel güven düzeyleri ve yıldırma arasındaki ilişkiyi, Yıldız (2013) öğretmenlerin örgütsel adalet ve örgütsel güven düzeyleri arasındaki ilişkiyi, Akın (2015) öğretmenlerin örgütsel sinizm ve örgütsel güven düzeyleri arasındaki ilişkiyi, Van Maele ve Van Houtte (2015) ilkokullarda görev yapan örgütsel güven ile öğretmenlerde tükenmişlik arasındaki ilişkiyi, Akın ve Orman (2015) öğretmenlerin örgütsel güven ile örgütsel bağlllık düzeyleri arasındaki ilişkiyi, Özer ve Akbaş (2016), öğretmenlerin okul kültürü profili ve örgütsel güvene ilişkin algıları arasındaki ilişkiyi, Adıgüzelli (2016) öğretmen görüşlerine göre dağıtılmış liderlik ile örgütsel güven arasındaki ilişkiyi, Sevinç ve Sağlam (2018) okul yöneticilerinin iletişim yeterliliklerine ilişkin öğretmen görüşleri ile öğretmenlerin örgütsel güven düzeyleri arasındaki ilişkiyi, Kovancı (2020) ilkokul öğretmenlerinin örgütsel güven algıları ile örgütlerine yabancılaşmaları arasındaki ilişkiyi incelemişlerdir.

Bu çalışmada ise örgütsel güven kavramı tek başına ele alınmış ve alt boyutları olan yöneticiye güven, meslektaşa güven ve paydaşlara güvenin, okulların istenilen amaçlara ulaşmasındaki önemini ortaya koymak, ortaokullarda görev yapan öğretmenlerin örgütsel güven algılarının cinsiyet, medeni durum, yaş, eğitim durumu, branş, mesleki kıdem ve görev yaptı̆̆ı okuldaki çalışma süresi gibi değişkenlerden etkilenip etkilenmediğinin değerlendirilmesi amaçlanmıştır.

\section{YÖNTEM}

\section{Araştırma Modeli}

Ortaokullarda görev yapan öğretmenlerin çeşitli değişkenlere göre örgütsel güven algılarının incelenmesinin amaçlandığı bu araştırmanın deseni, betimsel nitelikte tarama modelidir. Karasar'a (2003) göre tarama modeli, araştırmanın konusunu oluşturan birey, nesne veya olayın var olduğu biçimde ve kendi koşulları içerisinde tanımlanmaya çalışılır. Bu çerçevede araştırmada, ortaokullarda görev yapan öğretmenlerin örgütsel güven algıları bazı değişkenlere göre var olduğu biçimiyle incelenmiştir.

\section{Çalışma Grubu}

Araştırma çalışma grubu, örneklem belirleme yoluna gidilmeden 2018-2019 eğitim-öğretim yllındaki Sivas il merkezindeki 14 ortaokulda görevli 278 öğretmenden oluşmaktadır. Çalışma grubunda yer alan okulların ve öğretmenlerin belirlenmesinde gönüllülük esası temel alınmıştır. Bu kapsamda örgütsel güven ölçeğini yanıtlayan ortaokullarda görev yapan 278 öğretmene ilişkin kişisel bilgiler Tablo 1'de sunulmuştur:

Tablo 1. Katılımcı Öğretmenlere İlişkin Kişisel Bilgiler

\begin{tabular}{llll}
\hline Değişkenler & Kategoriler & Frekans (n) & $\begin{array}{l}\text { Yüzde( } \\
\text { \%) }\end{array}$ \\
\hline \multirow{3}{*}{ Cinsiyet } & Erkek & 137 & $49,3 \%$ \\
& Kadın & 141 & $50,7 \%$ \\
& Toplam & 278 & $100 \%$ \\
\hline \multirow{2}{*}{ Medeni Durum } & Evli & 234 & $84,2 \%$ \\
& Bekar & 44 & $15,8 \%$ \\
\hline \multirow{2}{*}{ Yaş Grubu } & Toplam & 278 & $100 \%$ \\
\hline & $20-30$ arası & 55 & $19,8 \%$ \\
& $31-40$ arası & 153 & $55,0 \%$ \\
& $41-50$ arası & 61 & $21,9 \%$ \\
\end{tabular}




\begin{tabular}{llll} 
& Toplam & 278 & $100 \%$ \\
\hline \multirow{2}{*}{ Eğitim Durumu } & Lisans & 253 & $90,6 \%$ \\
& Lisans Üstü & 25 & $9,0 \%$ \\
& Toplam & 278 & $100 \%$ \\
\hline \multirow{3}{*}{ Branşı } & Sayssal & 107 & $38,5 \%$ \\
& Sözel & 137 & $49,3 \%$ \\
& Özel Yetenek & 34 & $12,2 \%$ \\
& Toplam & 278 & $100 \%$ \\
\hline \multirow{3}{*}{ Meslekteki Hizmet Süresi } & 10 yıl ve daha az & 109 & $39,2 \%$ \\
& $10-20$ yıl & 132 & $47,5 \%$ \\
& 21 yıl ve üstü & 37 & $13,3 \%$ \\
& Toplam & 278 & $100 \%$ \\
\hline \multirow{2}{*}{ Okuldaki Hizmet Süresi } & 5 yll ve daha az & 176 & $63,3 \%$ \\
& $6-10$ yıl & 78 & $28,1 \%$ \\
\hline
\end{tabular}

Tablo 1'e göre katılımaların cinsiyete göre dağılımına bakıldığında 137'si (\% 49,3) erkek, 141'i $(\% 50,7)$ kadın öğretmen; medeni duruma göre 234 'ü $(\% 84,2)$ evli, 44'ü $(\% 15,8)$ bekâr öğretmen; yaş aralığına göre ise 55'i (\%19,8) "20-30 arası" yaş grubunda, 153'ü (\%55,0) “31-40 arası" yaş grubunda, 61'i (\%21,9) "41-50 arası" yaş grubunda, 9'u (\%3,2) "51 ve üzeri" yaş grubunda olduğu görülmektedir. Öğretmenlerin 1'i $(\% 0,4)$ "ön lisans", 252'si $(\% 90,6)$ "lisans" ve 25'i $(\% 9,0)$ "lisans üstü" mezun olduğu; 107 kişinin $(\% 38,5)$ sayısal, 137 kişini $(\% 49,53)$ sözel ve 34 kişinin $(\% 12,2)$ ise özel yetenek branşına sahip olduğu görülmektedir. Öğretmenlerin meslekteki hizmet süresi bazında 109' unun $(\% 39,2)$ "10 yıl ve altı" k1dem grubunda, 132'sinin $(\% 47,5)$ "10-20 yıl arası" kıdem grubunda ve 37'sinin (\%33) ise "21 yıl ve üstü" kıdem grubunda olduğu ve son olarak ise okuldaki hizmet süreleri bakımından öğretmenlerin 176'sı (\%63,3) “5 yıl ve alt", 78'i (\%28,1) “6-10 yıl arası", 22'si (\%7,9) "11-15 yıl arası" ve ikisi (\%0,7) "16 yıl ve üstü" olduğu görülmektedir.

\section{Veri Toplama Araci}

Araştırma verileri Hoy ve Tschannen-Moran (1999) tarafından geliştirilen ve Yilmaz (2006) tarafından Türkçeye uyarlanan üç alt boyutlu, 22 maddeden oluşan "Örgütsel Güven Ölçeği" aracılığıyla toplanmıştır. Beşli likert tipi bir ölçek olan örgütsel güven ölçeğinin geçerliliğini test etmek üzere yapılan faktör analizi sonucu yöneticiye güven, meslektaşlara güven ve paydaşlara güven olmak üzere dört faktörde toplandığ 1 ve toplam varyansın \%56,46 olarak bulunmuştur. Ölçekte yer alan maddelerin faktör yük değerleri .31 ile .74 arasinda değişmektedir. Araştırmada uygulanılan örgütsel güven ölçeğinin tamamının Cronbach-Alfa güvenilirlik katsayısı .91 olarak belirlenmesi kullanılan ölçeğin güvenilir olduğunu göstermektedir. Ölçeğin alt boyutlarına ilişkin güvenirlik katsayısı ise yöneticiye güven boyutunun Cronbach-Alfa güvenilirlik katsayısı .78, meslektaşlara güven boyutunun Cronbach-Alfa güvenilirlik katsayısı .92 ve paydaşlara güven boyutunun Cronbach-Alfa güvenilirlik katsayısı .88 olarak saptanmıştır.

Ölçek; (1) Hiçbir zaman, (2) Çok nadir, (3) Bazen, (4) Çoğunlukla ve (5) Her zaman şeklinde cevaplanmaktadır. Bu ölçekten alınan puanlar da, 1.00-1.80 arası çok düşük, 1.81-2.60 düşük, 2.61-3.40 orta, 3.41-4.20 yüksek ve 4.21-5.00 arası ise çok yüksek alg1 düzeyi şeklinde değerlendirilmiştir. Anket sorularını cevaplayan bireylerin yapılan ölçekten elde ettikleri 
toplam puan, görev yaptıkları okullardaki örgütsel güvene ait görüş düzeylerini ortaya koymaktadır. Çalışma sonucunda yüksek güven duygusunu öğretmenlerin her bir faktör için aldıkları yüksek puan yansıtırken, buna karşın düşük güven duygusunu öğretmenlerin her bir faktörden aldıkları düşük puan yansıtmaktadır.

Araştırmada kullanılan "Örgütsel Güven Ölçeği" için Sivas Cumhuriyet Üniversitesi Eğitim Bilimleri Enstitüsü aracılığıyla Sivas İl Milli Eğitim Müdürlüğünden alınan uygulama izni doğrultusunda araştırmacı tarafından 15.12.2018-10.01.2019 tarihleri arasında katılımcılara uygulanarak araştırma verileri toplanmıştır.

\section{Verilerin Analizi}

Araştırma verileri için SPSS 18,0 paket programı kullanarak yapılan analizde öncelikle, örgütsel güvene ilişkin algı düzeylerin bütün boyutları için Tek Örneklem Kolmogorov Smirnov Testi kullanılarak bütün boyutların normal dağılım gösterdiği tespit edilmiştir. Betimsel istatistiklerde yapılan levene testi sonuçlarına göre cinsiyet, medeni durum, eğitim durumu, yaş, meslekteki hizmet süresi ve görev yaptığı okuldaki hizmet süresi değişkeninde parametrik dağılımlar görülürken branş değişkeninde ise non parametrik dağılımın olduğu görülmüştür. Cinsiyet ve medeni durum değişkenine göre yapılan ikili karşılaştırmalarda ttesti; yaş, eğitim durumu, meslekteki hizmet süresi ve okuldaki hizmet süresi değişkenlerinde üç ve daha fazla boyutlu karşılaştırmalar olduğu için tek yönlü varyans analizi (ANOVA) kullanılmıştır. Branş değişkeninde ise non parametrik dağılım görüldüğü için Kruskal Wallis $\mathrm{H}$ Testi kullanılmıştır. Anlamlı çıkan F değerleri için, ortaya çıkan farkın kaynağını belirlemek üzere yaş, meslek hizmet süresi ve okuldaki hizmet süresi değişkenleri gibi çoklu karşılaştırma testlerinde Tukey-HSD testi kullanılmıştır. Veri analizlerinde, anlamlılık düzeyi .05 olarak kabul edilmiştir.

\section{BULGULAR}

Bu bölümde, öncelikle örgütsel güven ölçeği ve alt boyutlarına ait görüşlerine ilişkin aritmetik ortalama, standart sapma ve ölçek maddelerinin seçeneklerine göre ortaya çıkan sayısal (değerler) verilere yer verilmiştir. İkinci olarak ortaokullarda görev yapan öğretmenlerin çeşitli değişkenlere göre farklılaşıp farklılaşmadığını belirlemek için Tek Örneklem Kolmogorov Smirnov Testi kullanılarak varyansların homojen olup olmadığı test edilmiştir. Son olarak ortaokullarda görev yapan öğretmenlerin örgütsel güven algılarına ilişkin bulguları, cinsiyet, medeni durum, yaş, eğitim durumu, branş, meslekteki hizmet süresi ve okuldaki hizmet süresi değişkenlerine göre yorumlamak ve aralarındaki ilişkileri belirlemek amacıyla t testi, tek yönlü varyans ANOVA testi Tukey-HSD ve Kruskal-Wallis U testi bulguları sunulmuştur.

Tablo 2'de ortaokul öğretmenlerinin örgütsel güven ve alt boyutlarına göre betimsel istatistiklere ve algılama düzeyine ilişkin dağılımlar verilmiştir.

Tablo 2. Ortaokul Öğretmenlerinin Örgütsel Güven Ölçeğini Algılama Düzeylerine İlişkin Dă̆ılımı

\begin{tabular}{lcccc}
\hline Boyutlar & $\mathbf{N}$ & $\overline{\mathbf{X}}$ & ss & Düzey \\
\hline Yöneticiye Güven & 278 & 4,01 &, 63 & Yüksek \\
\hline Meslektaşlara Güven & 278 & 3,87 &, 64 & Yüksek \\
\hline Paydaşlara Güven & 278 & 3,34 &, 65 & Orta \\
\hline Genel & 278 & 3,78 &, 50 & Yüksek \\
\hline
\end{tabular}


Tablo 2'de örgütsel güven ölçeği ve alt boyutları, maddelerin seçeneklerine göre ortaya çıkan sayısal veriler dikkate alınarak analiz edildiğinde, çalışma grubunda yer alan ortaokul öğretmenlerin yöneticiye güven ve meslektaşlara güven boyutlarında "Yüksek"; paydaşlara güven boyutunda ise "Orta" düzeyde olduğu görülmektedir. Diğer yandan örgütsel güven ölçeğinin toplam aritmetik ortalamasının da "Yüksek" düzeyde olduğu saptanmıştır. Bu sonuçlara göre ortaokul öğretmenlerinin örgütsel güvene ilişkin algılarının yüksek düzeyde olumlu olduğu söylenebilir.

Öğretmenlerin örgütsel güvene ilişkin algı düzeylerinde demografik değişkenler açısından anlamlı bir farklılık olup olmadığı incelenmiştir. Ortaokul öğretmenlerinin algıladıkları örgütsel güven düzeyi genel ve alt boyutlarından elde ettikleri puanların cinsiyet değişkenine göre anlamlı bir farklılık gösterip göstermediği analiz edilirken, öncelikle varyansların homojenliği test edilmiştir (Levene I. Boyut $=.102, \mathrm{p}=.750$; Levene II. Boyut =.121, p=.729; Levene III. Boyut $=.919, \mathrm{p}=.338$ ve Levene Toplam $=.554, \mathrm{p}=.457)$. Yapilan analizler sonucunda tüm boyutlar için varyansların homojen olduğu belirlenerek parametrik testlerinden $t$ testi uygulanmıştır ve elde edilen sonuçlar Tablo 3 'te yer verilmiştir.

Tablo 3. Ortaokul Öğretmenlerinin Örgütsel Güven Algılarının Cinsiyet Değişkenine Göre T Testi Sonuçları

\begin{tabular}{|c|c|c|c|c|c|c|c|}
\hline Boyutlar & Cinsiyet & $\mathbf{N}$ & $\overline{\mathbf{X}}$ & ss & sd & $\mathbf{t}$ & $\mathbf{P}$ \\
\hline \multirow[t]{2}{*}{ Yöneticiye Güven } & Erkek & 137 & 4,07 & ,635 & \multirow{2}{*}{276} & \multirow{2}{*}{1,642} & \multirow{2}{*}{ 102 } \\
\hline & Kadın & 141 & 3,95 & 622 & & & \\
\hline \multirow[t]{2}{*}{ Meslektaşlara Güven } & Erkek & 137 & 3,94 & 640 & \multirow{2}{*}{276} & \multirow{2}{*}{1,919} & \multirow{2}{*}{,056 } \\
\hline & Kadın & 141 & 3,79 & 639 & & & \\
\hline \multirow{2}{*}{ Paydaşlara Güven } & Erkek & 137 & 3,52 & ,596 & \multirow{2}{*}{276} & \multirow{2}{*}{4,658} & \multirow{2}{*}{,000 } \\
\hline & Kadın & 141 & 3,17 & 661 & & & \\
\hline \multirow{2}{*}{ Genel } & Erkek & 137 & 3,88 & 480 & \multirow{2}{*}{276} & \multirow{2}{*}{3,541} & \multirow{2}{*}{000} \\
\hline & Kadın & 141 & 3,67 &, 507 & & & \\
\hline
\end{tabular}

${ }^{*} \mathrm{p}<.05$

Tablo 3'e göre ortaokul öğretmenlerinin yöneticiye güven [t(276)=1.642, $p=, 102]$ ve meslektaşlara güven [ $\mathrm{t}(276)=1.919, \mathrm{p}=, 056]$ boyutlarındaki algıları cinsiyet değişkenine göre anlamlı bir farklılık göstermemiştir. Diğer yandan paydaşlara güven [t(276) $=4.658, \mathrm{p}=, 000]$ boyutundaki algıları ile örgütsel güven $[t(276)=3.541, p=, 000]$ algılarında cinsiyet değişkenine göre anlamlı düzeyde bir farklılık olduğu görülmektedir. Paydaşlara güven boyutundaki gruplar incelendiğinde erkek öğretmenlerinin aritmetik ortalamalarının ( $\overline{\mathrm{X}}=3,52)$, kadın öğretmenlere $(\bar{X}=3,17)$ kıyasla daha yüksek olduğu saptanmıştır. Aynı şekilde geneldeki gruplar incelendiğinde de erkek öğretmenlerin $(\bar{X}=3,88)$ görev yaptıkları okullardaki örgütsel güven düzeyi algılarının, kadın öğretmenlere $(\bar{X}=3,67)$ göre daha yüksek olduğu bulgusuna ulaşılmıştır.

Ortaokul öğretmenlerinin örgütsel güven ölçeği ve alt boyutlarından elde ettikleri puanların medeni durumuna göre anlamlı bir farklılık gösterip göstermediğini belirlemek için önce varyansların homojenliği test edilmiştir (Levene I. Boyut $=.780, \mathrm{p}=.378$; Levene II. Boyut $=.844$, $\mathrm{p}=.355$; Levene III. Boyut $=.445, \mathrm{p}=.482$ ve Levene Toplam $=.001, \mathrm{p}=.950$ ). Yapilan analizler sonucunda tüm boyutlar için varyansların homojen olduğu belirlenerek parametrik testlerinden t testi uygulanmıştır ve elde edilen sonuçlar Tablo 4 'te yer almaktadır. 
Tablo 4. Ortaokul Öğretmenlerinin Örgütsel Güven Algılarının Medeni Durum Değişkenine Göre T- Testi Sonuçları

\begin{tabular}{|c|c|c|c|c|c|c|c|}
\hline & Medeni & & & ss & & & \\
\hline Boyutlar & Durum & $\mathbf{N}$ & $X$ & & sd & $t$ & $\mathbf{p}$ \\
\hline \multirow[t]{2}{*}{ Yöneticiye Güven } & Evli & 234 & 3,99 & 650 & 276 & $-1,664$ & 24 \\
\hline & Bekar & 44 & 4,11 & ,507 & & & \\
\hline \multirow[t]{2}{*}{ Meslektaşlara Güven } & Evli & 234 & 3,86 & 637 & 276 &,-285 & ,77 \\
\hline & Bekar & 44 & 3,89 & 678 & & & \\
\hline \multirow[t]{2}{*}{ Paydaşlara Güven } & Evli & 234 & 3,32 & ,641 & 276 & $-1,615$ & ,10 \\
\hline & Bekar & 44 & 3,49 & ,704 & & & \\
\hline \multirow[t]{2}{*}{ Genel } & Evli & 234 & 3,76 & ,508 & 276 & $-1,156$ & ,24 \\
\hline & Bekar & 44 & 3,86 & 481 & & & \\
\hline
\end{tabular}

${ }^{*} \mathrm{p}<.05$

Tablo 4'e göre örgütsel güven [ $t(276)=-1,156 \mathrm{p}=, 249$ ], yöneticiye güven [t(276) $=-1.664, \mathrm{p}=, 245$ ], meslektaşlara güven $[\mathrm{t}(276)=-.285 \mathrm{p}=, 776]$ ve paydaşlara güven $[\mathrm{t}(276)=-1.615, \mathrm{p}=, 107]$ algiları medeni durum değişkenine göre anlamlı bir farklılık görülmemektedir.

Ortaokul öğretmenlerin yaş değişkenine göre örgütsel güven ve alt boyutlarındaki algıları arasında anlamlı bir farklılığın oluşup oluşmadığını analiz etmek için öncelikle varyansların homojenliği test edilmiştir (Levene I. Boyut ( $p=.37, p>.05$ ); Levene II. Boyut ( $p=.35, p>.05$ ); Levene III. Boyut ( $\mathrm{p}=.48, \mathrm{p}>.05)$ ve Levene Toplam $(\mathrm{p}=.98, \mathrm{p}>.05))$. Yapilan analizler sonucunda tüm boyutlar için varyansların homojen olduğu belirlenerek öğretmenlerin örgütsel güven ölçeği ve alt boyutlarından elde ettikleri puanların yaş değişkenine göre algıları anlamlı bir farklılık gösterip göstermediğini belirmek için kullanılan ANOVA Testi sonuçlarına ilişkin veriler Tablo 5 'te yer almaktadır.

Tablo 5. Ortaokul Öğretmenlerinin Örgütsel Güven Algılarının Yaş Değişkenine Göre Anova Testi Sonuçları

\begin{tabular}{|c|c|c|c|c|c|c|}
\hline Boyutlar & & KT & $\mathrm{sd}$ & $\mathrm{KO}$ & $\mathrm{F}$ & $\mathrm{p}$ \\
\hline \multirow{3}{*}{ Yöneticiye Güven } & Gruplar Arası & 2,05 & 3 & 68 & & \\
\hline & Gruplar İçi & 108,08 & 274 & ,39 & 1,73 & , 16 \\
\hline & Toplam & 110,13 & 277 & & & \\
\hline \multirow{3}{*}{ Meslektaşlara Güven } & Gruplar Arası & ,78 & 3 & ,26 & & \\
\hline & Gruplar İçi & 113,90 & 274 & ,41 & 62 &, 59 \\
\hline & Toplam & 114,68 & 277 & & & \\
\hline \multirow{3}{*}{ Paydaşlara Güven } & Gruplar Arası & 4,74 & 3 & 1,58 & & \\
\hline & Gruplar İçi & 113,59 & 274 & 41 & 3,8 & ,01 \\
\hline & Toplam & 118,33 & 277 & & & \\
\hline \multirow{3}{*}{ Genel } & Gruplar Arası & ,72 & 3 & ,24 & & \\
\hline & Gruplar İçi & 69,75 & 274 & 25 & 94 & ,41 \\
\hline & Toplam & 70,48 & 277 & & & \\
\hline
\end{tabular}

${ }^{*} \mathrm{p}<.05$

Tablo 5'e göre ortaokul öğretmenlerinin paydaşa güven boyutu (F3-274=3,80 $p=$,01) hariç diğer alt boyutları olan yöneticiye güven (F3-274=1,73 $p=, 16$ ); meslektaşlara güven (F3-274= ,62 $p=, 59)$ boyutlarında ve genel güven algısında (F3-274= ,94 $p=, 41)$ anlamlı bir farklılığın olmadığı anlaşılmaktadır. Paydaşa güven boyutunda yaş değişkeni için var olan farklılığın 
tespitine yönelik olarak Tukey testi uygulanarak yaş gruplarında ikili karşılaştırılmalar yapılmıştır. Yapılan incelemede belirlenen anlamlı farkın 20-30 yaş grubunda olan öğretmenler ile 31- 40 ve 41-50 yaş gruplarındaki öğretmenler arasında olduğu anlaşılmaktadır. 20-30 yaş grubunda olan branş öğretmenlerinin puanları, 31-40 ve 41-50 yaş gruplarında yer alan branş öğretmenlerinin puanlarından anlamlı düzeyde düşük olmasından kaynaklanmaktadır.

Ortaokul öğretmenlerin branş değişkenine göre örgütsel güven ve alt boyutlarındaki algıları arasında anlamlı bir farklılığın olup olmadığının analizini yapmak için ilk olarak varyansların homojenliği test edilmiştir ve yapılan analiz sonucunda "Meslektaşa Güven" Levene II. Boyut $(\mathrm{p}=.03, \mathrm{p}>.05)$ hariç ölçeğin diğer boyutları olan (Yöneticiye Güven Levene I. Boyut ( $\mathrm{p}=.53$, $\mathrm{p}>$.05); Paydaşlara Güven Levene III. Boyut ( $\mathrm{p}=.31, \mathrm{p}>.05)$ ve Toplam Ölçek Levene Genelde $(\mathrm{p}=.14, \mathrm{p}>.05)$ ) varyansların homojen dağıldı $\breve{g}_{1}$ belirlenmiştir. İkinci olarak öğretmenlerin branş değişkenine göre örgütsel güven (genel) ve yöneticiye güven, paydaşlara güven alt boyutlarındaki algıları arasında anlamlı bir farklılığın görülüp görülmediğini belirmek için kullanılan ANOVA Testi sonuçlarına ait veriler Tablo 6' da yer almaktadır.

Tablo 6. Ortaokul Öğretmenlerinin Örgütsel Güven Algılarının Branş Değişkenine Göre Anova Testi Sonuçları

\begin{tabular}{|c|c|c|c|c|c|c|}
\hline Boyutlar & & KT & sd & $\mathrm{KO}$ & $\mathrm{F}$ & $\mathrm{P}$ \\
\hline \multirow{3}{*}{ Yöneticiye Güven } & Gruplar Arası & 122 & 2 & ,061 & & \\
\hline & Gruplar İçi & 110,016 & 275 & ,400 & 15 & ,85 \\
\hline & Toplam & 110,138 & 277 & & & \\
\hline \multirow{3}{*}{ Paydaşlara Güven } & Gruplar Arası & ,248 & 2 & ,124 & & \\
\hline & Gruplar İçi & 118,085 & 275 & 429 & ,28 & ,74 \\
\hline & Toplam & 118,333 & 277 & & & \\
\hline \multirow{3}{*}{ Genel } & Gruplar Arası & 440 & 2 & ,220 & & \\
\hline & Gruplar İçi & 70,041 & 275 & ,255 & 86 & ,42 \\
\hline & Toplam & 70,481 & 277 & & & \\
\hline
\end{tabular}

${ }^{*} \mathrm{p}<.05$

Tablo 6'deki bulgulara göre ortaokul öğretmenlerinin genel örgütsel güven (F 2- 275= ,86 p= ,42); yöneticiye güven (F 2- 275=,15 $p=, 85$ ) ve paydaşlara güven (F 2-275= ,86 $p=, 42$ ) alg1ları branş değişkenine göre anlamlı bir farklılık görülmemiştir. Son olarak ise meslektaşa güven boyutunda gruplar varyansın eşit olmamasından dolayı güven algıları arasında anlamlı bir farklılığın olup olmadığını belirmek için kullanılan Krusukal-Wallis H Testi Tablo 7'de özetlenmiştir.

Tablo 7. Ortaokul Öğretmenlerinin Meslektaşa Güven Boyutu Algılarının Branş Değğiskenine Göre Krusukal-Wallis H Testi Sonuçları

\begin{tabular}{lccccc}
\hline Meslektaşlara Güven Boyutu & N & $\begin{array}{c}\text { Sira } \\
\text { Ortalaması }\end{array}$ & s.d & $\mathbf{x}^{\mathbf{2}}$ & P \\
\hline Sayısal & 107 & 139,70 & 2 & 5,16 &, 07 \\
\hline Sözel & 137 & 146,31 & & \\
\hline Özel Yetenek & 34 & 111,44 & & \\
\hline Toplam & 278 & & & \\
\hline
\end{tabular}

${ }^{*} \mathrm{p}<.05$ 
Tablo 7'deki bulgulara göre ortaokul öğretmenlerinin meslektaşa güven boyutunda $\left(\mathrm{x}^{2}=\right.$ $5,16 ; \mathrm{sd}=2 ; 0,5)$ anlamlı bir farklılı̆̆ın olmadığı anlaşılmaktadır.

Ortaokul öğretmenlerin mesleki hizmet süresi değişkenine göre örgütsel güven ve alt boyutlarındaki algıları arasında anlamlı bir farklılığın olup olmadığını ortaya çıkarmak için ilk olarak varyansların homojenliği test edilmiştir (Yöneticiye Güven Levene I. Boyut ( $p=.06$, $\mathrm{p}>$.05); Meslektaşa Güven Levene II. Boyut ( $\mathrm{p}=.78, \mathrm{p}>.05)$; Paydaşlara Güven Levene III. Boyut $(p=.12, p>.05)$ ve Toplam Ölçek Levene Genelde $(p=.12, p>.05)$ ). Yapılan analizler sonucunda tüm boyutlar için varyansların homojen olduğu belirlenerek öğretmenlerin örgütsel güven ölçeği ve alt boyutlarından elde ettikleri puanların mesleki hizmet süresi değişkenine ait anlamlı düzeyde bir farklılığın olup olmadığını belirmek için kullanılan ANOVA Testi sonuçlarına ait veriler Tablo 8' de yer almaktadır.

Tablo 8. Ortaokul Öğretmenlerinin Örgütsel Güven Algılarının Mesleki Hizmet Süresi Değişkenine Göre Anova Testi Sonuçları

\begin{tabular}{|c|c|c|c|c|c|c|}
\hline Boyutlar & & $\mathrm{KT}$ & $\mathrm{sd}$ & $\mathrm{KO}$ & $\mathrm{F}$ & $\mathrm{p}$ \\
\hline \multirow{3}{*}{ Yöneticiye Güven } & Gruplar Arası & 2,05 & 3 & 68 & & \\
\hline & Gruplar İçi & 108,08 & 274 & ,39 & 1,73 & , 16 \\
\hline & Toplam & 110,13 & 277 & & & \\
\hline \multirow{3}{*}{ Meslektaşlara Güven } & Gruplar Arası & ,78 & 3 & 26 & & \\
\hline & Gruplar İçi & 113,90 & 274 & ,41 & ,62 &, 59 \\
\hline & Toplam & 114,68 & 277 & & & \\
\hline \multirow{3}{*}{ Paydaşlara Güven } & Gruplar Arası & 4,74 & 3 & 1,58 & & \\
\hline & Gruplar İçi & 113,59 & 274 &, 41 & 3,8 & ,01 \\
\hline & Toplam & 118,33 & 277 & & & \\
\hline \multirow{3}{*}{ Genel } & Gruplar Arası & 72 & 3 & ,24 & & \\
\hline & Gruplar İçi & 69,75 & 274 & 25 & ,94 & ,41 \\
\hline & Toplam & 70,48 & 277 & & & \\
\hline
\end{tabular}

${ }^{*} \mathrm{p}<.05$

Tablo 8'e göre ortaokul öğretmenlerinin yöneticiye güven (F2-275=1,97 $p=, 14)$ ve meslektaşlara güven (F2-275= 1,56 $p=, 21)$ boyutlarındaki algıları mesleki hizmet süresi değişkenine göre anlamlı bir farklılık göstermemiştir. Diğer yandan paydaşlara güven (F2-275= $5,32 p=, 05)$ boyutundaki algıları ile örgütsel güven (F2-275=3,67 $p=, 02$ ) algılarında mesleki hizmet süresi değişkenine göre anlamlı bir farklılığın görüldüğü anlaşılmaktadır. Tespit edilen anlamlı farklılığın hangi gruplar arasında meydana geldiğini ortaya koymak için Tukey testi uygulanarak ikili karşılaştırmalar yapılmıştır. Bunun sonucunda paydaşlara güven boyutundaki gruplar incelendiğinde oluşan fark hizmet süresi 10 yıl ve daha az ögretmenlerinin aritmetik ortalamalarının $(\overline{\mathrm{X}}=3,19)$, hizmet süresi $10-20$ yıl olan öğretmenlerinin aritmetik ortalamaları $(\bar{X}=3,43)$ ve hizmet süresi 21 yıl ve üstü olan öğretmenlerinin aritmetik ortalamalarına $(\bar{X}=3,43)$ kıyasla daha düşük olmasından kaynaklanmaktadır. Aynı şekilde geneldeki gruplar incelendiğinde de oluşan anlamlı fark hizmet süresi 10 yıl ve altı grubundaki öğretmenler ile hizmet süresi 10-20 yıl olan öğretmenler arasındadır. Aynı okulda çalışma süresi 10 yıl ve daha az olan öğretmenlerinin aritmetik ortalamalarının $(\overline{\mathrm{X}}=3,68)$ olması, genel ortalamadan $(\overline{\mathrm{X}}=3,78)$ uzaklaşmış olduğu görülmektedir. 
Yapılan analizler sonucunda tüm boyutlar için varyansların homojen olduğu belirlenerek öğretmenlerin örgütsel güven ölçeği ve alt boyutlarından elde ettikleri puanların eğitim durumu değişkenine göre anlamlı bir farklılığın olup olmadığını belirmek için kullanılan ANOVA Testi sonuçlarına ait veriler Tablo 6' da yer almaktadır.

Tablo 9. Ortaokul Öğretmenlerinin Örgütsel Güven Algılarının Eğitim Durumu Değişkenine Göre Anova Testi Sonuçları

\begin{tabular}{|c|c|c|c|c|c|c|}
\hline Boyutlar & & KT & sd & $\mathrm{KO}$ & $\mathrm{F}$ & $\mathrm{P}$ \\
\hline & Gruplar Arası & 1,92 & 2 & ,96 & & \\
\hline \multirow[t]{3}{*}{ Yöneticiye Güven } & Gruplar İçi & 108,21 & 275 & ,39 & 2,45 & ,88 \\
\hline & Toplam & 110,13 & 277 & & & \\
\hline & Gruplar Arası & 79 & 2 & ,39 & & \\
\hline \multirow[t]{3}{*}{ Meslektaşlara Güven } & Gruplar İçi & 113,89 & 275 & ,41 & ,95 & , 38 \\
\hline & Toplam & 114,68 & 277 & & & \\
\hline & Gruplar Arası &, 47 & 2 & ,23 & & \\
\hline \multirow[t]{3}{*}{ Paydaşlara Güven } & Gruplar İçi & 117,85 & 275 & ,42 & ,55 &, 57 \\
\hline & Toplam & 118,33 & 277 & & & \\
\hline & Gruplar Arası & ,25 & 2 & ,12 & & \\
\hline \multirow[t]{3}{*}{ Genel } & Gruplar İçi & 70,22 & 275 & ,25 & ,49 & 61 \\
\hline & Toplam & 70,48 & 277 & & & \\
\hline & Toplam & 70,48 & 277 & & & \\
\hline
\end{tabular}

${ }^{*} \mathrm{p}<.05$

Tablo 6'daki bulgulara göre ortaokul öğretmenlerinin örgütsel güven (F 2- 275=,49 $p=$,61); yöneticiye güven ( $\mathrm{F} 2-275=2,45 p=, 88)$; meslektaşlara güven (F 2-275 $=, 95 p=, 38$ ) ve paydaşlara güven (F 2-275= ,55 $p=$,57) algıları eğitim durumu değişkenine göre anlamlı bir farklılık görülmemiştir.

Yapılan analizler sonucunda tüm boyutlar için varyansların homojen olduğu belirlenerek öğretmenlerin örgütsel güven ölçeği ve alt boyutlarından elde ettikleri puanların görev yaptıkları okuldaki hizmet süresi değişkenine göre anlamlı düzeyde bir farklılık gösterip göstermediğini belirmek için kullanılan ANOVA Testi sonuçlarına ait veriler Tablo 10'da verilmektedir.

Tablo 10. Ortaokul Öğretmenlerinin Örgütsel Güven Algılarının Görev Yaptıklarn Hizmet Süresi Değişkenine Göre Anova Testi Sonuçları

\begin{tabular}{|c|c|c|c|c|c|c|}
\hline Boyutlar & & KT & sd & $\mathrm{KO}$ & $\mathrm{F}$ & $\mathrm{P}$ \\
\hline & Gruplar Arası & 1,75 & 3 &, 58 & & \\
\hline \multirow[t]{3}{*}{ Yöneticiye Güven } & Gruplar İçi & 108,38 & 274 & ,39 & 1,47 & ,22 \\
\hline & Toplam & 110,13 & 277 & & & \\
\hline & Gruplar Arası & ,14 & 3 & ,04 & & \\
\hline \multirow[t]{3}{*}{ Meslektaşlara Güven } & Gruplar İçi & 114,54 & 274 & ,41 & ,11 & ,95 \\
\hline & Toplam & 114,68 & 277 & & & \\
\hline & Gruplar Arası & 3,64 & 3 & 1,21 & & \\
\hline \multirow[t]{3}{*}{ Paydaşlara Güven } & Gruplar İçi & 114,69 & 274 & 41 & 2,90 & , 03 \\
\hline & Toplam & 118,33 & 277 & & & \\
\hline & Gruplar Arası & 1,13 & 3 & ,37 & & \\
\hline Genel & Gruplar İçi & 69,34 & 274 & ,25 & 1,49 & 21 \\
\hline
\end{tabular}




Toplam $\quad 70,48 \quad 277$

$$
{ }^{*} \mathrm{p}<.05
$$

Tablo 10'daki bulgulara göre ortaokul öğretmenlerinin genel örgütsel güven (F3-274=1,49 $p=$ ,21); yöneticiye güven ( $\mathrm{F} 3-274=1,47 p=, 22)$ ve meslektaşa güven (F3-274=,11 $p=, 95)$ algılar1 branş değişkenine göre anlamlı bir farklılık görülmemiştir. Diğer yandan paydaşlara güven boyutunda (F3-274= 2,90 p= ,03) öğretmenlerin güvene ilişkin.algılarında görev yaptıkları okuldaki hizmet süresi değişkenine göre anlamlı bir farklılık olduğu anlaşılmaktadır. Farklılığın hangi gruplar arasında olduğunu belirleyebilmek için Tukey testi uygulanarak ikili karşılaştırmalar yapılmıştır. Yapılan test sonucunda saptanan anlamlı farklılığın görev yaptığı okulda çalışma süresi beş yıl ve daha az olan öğretmenlerin $(\overline{\mathrm{X}}=3,26)$ aritmetik ortalama puanlarının görev yaptığı okulda çalışma süresi 6-10 yıl olan öğretmenlerin aritmetik ortalama puanlarından $(\overline{\mathrm{X}}=3,51)$ daha düşük düzeyde olmasından kaynaklandığı belirlenmiştir.

\section{TARTIŞMA, SONUÇ ve ÖNERİLER}

Araştırma bulgularına göre öğretmenlerin genel olarak örgütsel güvene ilişkin algılarının yüksek düzeyde olduğu saptanmıştır. Katılımcıların örgütsel güvene ilişkin algı düzeyleri boyutlar bağlamında incelendiğinde yöneticiye güven ve meslektaşa güven boyutlarının yüksek düzeyde, paydaşlara güven boyutunun orta düzeyde olduğu görülmüştür. Yöneticiye ve meslektaşa güven boyutları yüksek düzeyde aralığında olmasına rağmen yöneticiye güven boyutunun aritmetik ortalama bağlamında daha yüksek olduğu tespit edilmiştir. Bu sonuçtan hareketle, öğretmenlerin görev yaptıkları okulda en çok yöneticilerine güvendiği söylenebilir. Okul ortamında yöneticiye güven duyulmasının okul gelişimi, okulda işbirliği, takım çalışması, ortak hedeflere yönelme ve öğretmen motivasyonu bağlamında olumlu sonuçlar ortaya çıkarabileceği söylenebilir. Sipahioğlu ve Öner (2013) ve Polat ve Celep (2008) tarafından yapılan araştırmalar bu çalışma sonuçlarıyla ile benzerlik göstermektedir.

Araştırmaya katılan öğretmenlerin algıladıkları örgütsel güven düzeyi, cinsiyet değişkenine göre anlamlı düzeyde farklılık göstermiştir ve erkek öğretmenlerin kadın öğretmenlere göre güven düzeyinin daha yüksek olduğu sonucuna ulaşılmıştır. Alt boyutlar incelediğinde ise yöneticiye güven ve meslektaşa güvende bir farklılık görülmezken paydaşlara güven boyutunda anlamlı bir farklılığın oluştuğu görülmektedir. Yılmaz (2006) yaptığı araştırmada erkek öğretmenlerin güven düzeyinin bütün boyutlarda yüksek düzeyde olmasını yaşadığımız çevrede erkek ve kız çocuklarının yetiştirilmesinde görülen anlayışın ve beklentilerin farklı olmasından kaynaklandığı şeklinde açıklamaktadır. Bu bağlamda ilgili literatür incelemesi yapıldığında (Özdil, 2005; Yılmaz, 2006; Polat ve Celep, 2008; Çağlar, 2011) tarafından yapılan çalışmalarda bu araştırmayı destekleyen benzer sonuçlar ortaya çıkarken Artuksi (2009) ve Öztürk (2012) tarafından yapılan çalışmalarda ise kadın öğretmenlerin güven düzeyinin erkek öğretmenlerin güven düzeyinden daha yüksek olduğu sonucuna ulaşılmıştır. Araştırmalarda, cinsiyet değişkenine bağlı olarak ortaya çıkan farklı sonuçların araştırmaların yapıldığı bölgelerin sosyal, kültürel ve ekonomik dinamiklerinin çeşitliliğinden kaynaklandığı söylenebilir.

Görev yapılan okuldaki hizmet süresi değişkeni öğretmenlerin örgütsel güven algilarını etkilediği görülmektedir. Boyutlar olarak incelendiğinde yöneticiye güven ve meslektaşa güven boyutunda anlamlı bir düzeyde farklılık oluşmazken paydaşlara güven boyutunda 
anlamlı düzeyde bir farklılığın oluştuğu görülmektedir. Saptanan anlamlı farkın 5 yıl ve daha az okulda çalışma süresi olan öğretmenler $(X=3,26)$ ile 6-10 yıl arası okulda çalışma süresi olan öğretmenler $(X=3,51)$ arasında olduğu anlaşılmaktadır. Bu farkın okulda çalışma süresi 5 yıl ve daha az olan öğretmenlerin ortalama puanlarının okulda çalışma süresi 6-10 yıl arası olan öğretmenlerin ortalama puanlarından anlamlı düzeyde düşük olmasından kaynaklandığ1 tespit edilmiştir. Bu bağlamda öğretmenlerin kurumda çalışma süreleri uzadıkça örgütsel güven algıları düzeyi de artmaktadır. Bir organizasyonda kalma süresi uzadıkça o organizasyona bağlılığın artacağı temel kabulü ile hareket edilirse araştırmamızın bu sonucu bekleneni yansıtması olarak değerlendirilebilir. Bireyin ortak bir hedefi gerçekleştirmesi amacıyla içinde bulunduğu kurumun faaliyetlerinde yer alma süresinin artması, o kuruma olan aitlik duygusunun artacağı düşüncesinden yola çıkarak, çalışmamızda çıkan bu sonuçla istenileni aksettirmesi şeklinde değerlendirilebilir. Örgütsel güven konusu ile ilgili Bilgiç (2011), Çintay (2013) ve Güneş, (2014) tarafından yapılan araştırmalar incelendiğinde öğretmenlerin örgütsel güven algı düzeylerinin hem genel boyut hem de alt boyutlar bazında görev yaptığı okuldaki çalışma süresinden etkilenmezken Çınar (2013) tarafından yapılan araştırmada ise örgütsel güven alg1 düzeylerinin hem genel boyut hem de alt boyutlar bazında görev yaptığı okuldaki çalışma süresinden etkilendiği sonucuna ulaşılmıştır.

Öğretmenlerin yöneticiye güven, meslektaşa güven ve paydaşlara güven alt boyutları ile eğitim durumu ile arasında anlamlı bir farkın bulunmadığı saptanmıştır. Çintay (2013) ve Gökduman, (2012) tarafından yapılan çalışmalarda da benzer bir şekilde öğretmenlerin eğitim durumları ile örgütsel güven algıları arasında örgütsel güvenin hiç bir alt boyutunda anlamlı farklılık bulamazken Uysal (2014) tarafından yapılan araştırmada yöneticiye güven boyutunda öğretmenlerin örgütsel güven algılarının farklılaştı̆̆ını saptamışlardır. Öğretmenlerin görev yaptıkları okuldaki yöneticilerine duydukları güven algılarında görülen bu farklılaşmanın eğitim durumu yüksek okul olan öğretmenler ile eğitim durumu lisans olan öğretmenler arasında olduğu görülmektedir. Literatürde örgütsel güven konusunda yapılmış araştırmalara bakıldığında (Polat, 2007; Halis ve diğerleri, 2007; Özgan, 2011; Baş ve Şentürk, 2011) tarafından yapılan araştırmalar eğitim seviyesi ile örgütsel güven arasında negatif yönlü (eğitim düzeyi artıkça örgütsel güven düzeyinin düştüğü); (İşcan ve Sayın, 2010; Gökduman, 2012; Uysal, 2014) tarafından yapılan araştırmalarda ise pozitif yönlü (eğitim düzeyi artıkça örgütsel güven seviyesinin de arttığı) ilişki olduğunu ortaya koymuşlardır. Eğitim durumu değişkenine göre ortaya çıkan farklı bulguların, araştırmaların yapıldığı bölgelere göre farklılaştığı söylenebilir.

Araştırmaya katılan öğretmenlerin örgütsel güven algıları branşına göre değişmemektedir. Benzer bulgulara Karabıyık (2012) ulaşırken Artuksi (2009) ise sadece iletişim alt boyutunda anlamlı bir farklılığın oluştuğu saptamıştır. Öğretmenlerin okul içinde kurdukları etkili iletişim kanallarının okul iklimini ve kültürünü olumlu etkileyeceği bilinmektedir. İletişim kanallarının açık ve karşılıklı olması okulda güven ortamı oluşmasını destekleyecektir. Bu araştırma kapsamında branş değişkenine göre anlamlı farklılıklar ortaya çıkmasa da, literatürde ortaya çıkan (Karabıyık, 2012; Artuksi, 2009) farklılıklar branş değişkeninin örgütsel güven üzerinde etkili olabileceğini göstermesi açısından önemlidir.

Medeni durum açısından ortaokullarda görev yapan öğretmenlerin örgütsel güven algılarının farklılık göstermediği görülmüştür. Buna göre öğretmenlerin örgütsel güven algılarının evli ya da bekâr olmalarından etkilenmediği söylenebilir. Medeni durum ile ilgili olarak Gören ve 
Özdemir'in (2015) yaptığı çalışmada öğretmenlerin örgütsel güven algılarının medeni duruma göre değişmediği sonucuna ulaşması bu araştırmanın sonucuyla örtüşmektedir.

Araştırma sonuçları yaş değişkeni kapsamında incelendiğinde öğretmenlerin örgütsel güven algılarının yöneticiye güven ve meslektaşa güven boyutunda bir farklılık oluşmazken paydaşlara güven boyutunda farklılık oluşmaktadır. Farklılığın oluştuğu paydaşlara güven boyutundaki gruplar incelendiğinde 20- 30 yaş aralığında olan öğretmenlerin ortalama puanlarının 31-40 ve 41-50 yaş aralığındaki öğretmenlerin ortalama puanlarından anlamlı düzeyde düşük olmasından kaynaklandığı saptanmıştır. Öğretmenlerin 31-40 ve 41-50 yaş grupları bulguları bağlamında öğretmenlerin yaşları ilerledikçe örgütsel güvene ilişkin algı düzeylerinin arttığı söylenebilir. Polat (2007), Ayduğ (2014), Çağlar (2011) ve Altun'un (2010) yaptıkları çalışmalarda "Meslektaşlara Güven" ve "Yöneticiye Güven" boyutlarındaki algılarının yaş değişkenine göre farklılık göstermediği ile ilgili sonuç, bu çalışmanın sonuçları ile benzerlik göstermektedir. Bu araştırmada, öğretmenlerin yaşı arttıkça paydaşlara güven alt boyutunda ortaya çıkan anlamlı ilişki düzeyinin nedenine ilişkin nitel çalışmaların yapılmasının uygun olacağı söylenebilir.

Kıdem değişkeni için öğretmenlerin örgütsel güven algıları boyutlar olarak incelendiğinde yöneticiye güven ve meslektaşa güven boyutunda anlamlı düzeyde bir farklılık göstermezken paydaşlara güven boyutunda ise anlamlı bir farklılık oluştuğu görülmektedir. Paydaşlara güven boyutunda oluşan anlamlı farklılık meslekteki hizmet süresi 10 yıl ve daha az olan öğretmenler ile mesleki hizmet süresi $10-20$ yıl arası ve 21 yıl üstü gruplarında yer alan öğretmenler arasındadır. Meslekte hizmet süresi 10 yıl ve daha az olan öğretmenlerin örgütsel güven ortalaması en düşük olan grup olduğu ortaya çıkmıştır. Diğer bir ifade ile 10 yıl ve daha az meslekte hizmet süresi olan öğretmenler diğer iki gruptan alg1 düzeylerindeki düşüklüğü sebebiyle farklılaşmaktadır. Artuksi (2009), Bilgiç (2011) ve Öztürk (2012) tarafından yapılan araştırmaların sonucunda mesleki kıdem ile örgütsel güven algıları arasında anlamlı bir farklılaşmanın olması bu çalışmanın sonucu ile örtüştüğünü göstermektedir. Diğer yandan Culver (1994), Zafer Güneş (2004), Özer ve diğerleri (2006), Altun (2010), Karaçay-Sevik (2012), Taşdan (2012) ve Eğriboyun (2013), tarafından yapılan çalışmalarda örgütsel güven algısının kıdem değişkenine göre anlamlı düzeyde farklılaşmaması bu çalışmayla örtüşmediğini göstermektedir.

Araştırma çerçevesinde aşağıdaki önerilerde bulunulmuştur:

Çalışmamızda cinsiyet değişkene dair örgütsel güven düzeyleri bakımından ele alındığında erkek öğretmenlerin kadın öğretmenlerden daha yüksek olduğu sonucu ortaya çıkmıştır. Bu sonuçtan hareketle bayan öğretmenlerin karar alma sürecine etkin bir şekilde katılmalarına ve kendilerini ifade etmesine olanak verilebilir. Bununla birlikte mevcut durumdan daha fazla yönetici pozisyonlarında görev alabilmesi için gerekli özen ve imkanlar sunulmalıdır.

Çalışmaya katılan öğretmenler arasında gerek yaş gerekse kıdem olarak genç ve göreve yeni başlayan öğretmenlerin örgütsel güven alg1 düzeylerinin diğer gruplarda yer alan öğretmenlere göre daha düşük düzeyde olduğu sonucunun ortaya çıkmasından hareketle mesleğe yeni başlayan öğretmenlere merkezi ya da mahalli hizmet içi kursları, seminerler ve eğitimler düzenlenerek görev yaptığı okullara uyum sağlamalarını hızlandırıcı çalışmalarla katkı sağlanabilir. 
Bulunduğu okulda görevine yeni başlayan öğretmenlerin okul çalışmalarında daha etkin olmalarını sağlayıcı vazifeler verilmelidir ve bu öğretmenler için sosyalleşebilmesi adına uyum programları yapılmalıdır.

Örgütsel güvenin okullarda istenilen hedeflerin gerçekleştirmesinde etkili olduğu söylenebilir. $\mathrm{Bu}$ bağlamda okullarda güven ikliminin sağlanabilmesi açısından öğretmenlerin görev hayatına başlamadan lisans eğitiminde ve lisansüstü eğitimlerinde güvenin ders ya da konu (içerik) olarak verilmelidir.

Milli Eğitim Bakanlığı tarafından okulun bütün paydaşları için örgütsel güven ile ilgili seminer programlarına ve çalışmalara yer verilmesi, okulda örgütsel güven ortamının gelişmesine katk1 sağlayacaktır.

Örgütsel güven konusunda yapılan bu araştırma ortaokul kurumlarında yapılandırılmıştır. İlkokul, ortaöğretim ve yükseköğretim kademelerinde karşılaştırmalı olarak farklı araştırmalar yapılabilir. Öte yandan okulun türü, öğrenci sayısı, bulunduğu mahalle gibi birçok değişken örgütsel güven algı düzeyini etkilemektedir. Bu noktadan hareketle, farklı yer, tür ve büyüklükteki okullara yönelik yeni çalışmalar yapılması okulların örgütsel güven düzeyleri hakkında daha ayrıntılı değerlendirmeler yapılabilmesi literatüre katkı sağlayabilir.

\section{KAYNAKÇA}

Adıgüzelli, Y. (2016). Dağıtılmış liderlik ile örgütsel güven arasindaki ilişkinin öğretmen görüşlerine göre incelenmesi. Ĕ̆itim ve Bilim, 41(185), 269-280.

Akın, U. (2015). Okullarda örgütsel sinizm ve güven ilişkisinin incelenmesi: Öğretmenler üzerinde bir araştırma. Eğitim ve Bilim, 40(181), 175-189.

Akın, U., \& Orman, E. (2015). The relationship between teachers' organizational trust and organizational commitment levels. SDU International Journal of Educational Studies,2(2), 92-102.

Altun, G. (2010). Özel eğitim kurumlarında çalışan öğretmenlerin örgütsel güven düzeyleri ile örgütsel bağgllıkları arasındaki ilişkinin incelenmesi. Yayınlanmamış yüksek lisans tezi, Marmara Üniversitesi Eğitim Bilimleri Enstitüsü, İstanbul.

Asunakutlu, T. (2002). Örgütsel güvenin oluşturulmasına ilişkin unsurlar ve bir değerlendirme. Muğla Üniversitesi Sosyal Bilimler Enstitüsü Dergisi, (9), 1-13.

Arslan, Ö. E. (2018). Örgütsel adalet, örgütsel anomi ve örgütsel güven arasındaki ilişki: otel işletmelerinde bir araştırma. Yayınlanmamış doktora tezi, Gazi Üniversitesi, Eğitim Bilimleri Enstitüsü, Ankara.

Artuksi, E. (2009). Illköğretim okullarında görevli öğretmenlerin okulun örgütsel güven düzeyine ilişkin algıları. Yayınlanmış yüksek lisans tezi, İnönü Üniversitesi Sosyal Bilimler Enstitüsü, Malatya.

Ayduğ, D. (2014). İlkokulların örgüt sağhlğg ile öğretmenlerin örgütsel güven düzeyleri arasındaki ilişkilerin incelenmesi. Yayınlanmamış yüksek lisans tezi, Anadolu Üniversitesi Eğitim Bilimleri Enstitüsü, Eskişehir. 
Baş, G. ve Şentürk, C. (2011). İlköğretim okulu öğretmenlerinin örgütsel adalet, örgütsel vatandaşlık ve örgütsel güven algıları. Kuram ve Uygulamada Ĕ̆itim Yönetimi, 1(1), 2962.

Bilgiç, Ö. (2011). Illköğretim okulu öğretmenlerinin örgütsel güven düzeyine ilişkin algılar (Küçükçekmece Örneği). Yüksek lisans tezi, Yıldız Teknik Üniversitesi, Sosyal Bilimler Enstitüsü, İstanbul.

Brehrn, J., ve Scott, G. (2002). Rules, trust, and the allocation of time. Paper presented at the Annual Meeting of the Midwest Political Science Association. Chicago, IL, April 25-28.

Candan, H. (2014). Çalışanların örgütsel adalet ve örgütsel güven algılamalarının örgütsel bağlllığa etkisi: bir kamu kurumu üzerinde araştırma. Gaziantep University Journal of Social Sciences, 13(4), 889-917.

Cemaloğlu, N., \& Kılınç, A. (2012). Okul müdürlerinin liderlik stilleri ile öğretmenlerin örgütsel güven düzeyleri arasındaki ilişki. Mehmet Akif Ersoy Üniversitesi Eğitim Fakültesi Dergisi, 1(23), 132-156.

Cerit, Y. (2009). Öğretmenlerin örgütsel güven düzeyleri ile işbirliği yapma düzeyleri arasındaki ilişki. Uludağ Üniversitesi Eğitim Fakültesi Dergisi, 22(2), 637-657.

Culver, T. R.(1994). "Influence strategies and trust in public schools", Seattle University, Education, Administration (0514); Edd Business Administration, Management (0454); Political Science, Public Administration (0617) ProQuest Information and Learning.

Çağlar Ç. (2011). Okullardaki örgütsel güven düzeyi ile öğretmenlerin mesleki tükenmişlik düzeyinin bazı değişkenler açısından incelenmesi. Kuram ve Uygulamada Eğitim Bilimleri, 11(4), 1827-1847.

Çınar, K. (2013). Ortaöğretim öğretmenlerinin örgütsel güven düzeylerine yöneticilerinin farkllıklarla yönetim davranışlarının etkisi. Yayımlanmamış yüksek lisans tezi, Cumhuriyet Üniversitesi, Sivas.

Çintay, H. (2013). Meslek liselerinde öğretmenlerin örgütsel güven algıları: İzmir ili örneği. Yayımlanmamış yüksek lisans tezi, Dokuz Eylül Üniversitesi, İzmir.

Erdem, F. (2003). Örgütsel yaşamda güven. (Ed. Ferda Erdem) Sosyal bilimlerde güven içinde. Ankara: Vadi.

Egriboyun, D. (2013). Ortaögretim okullarında görev yapan yönetici ve ögretmenlerin örgütsel güven, örgütsel destek ve örgütsel baglılıkları arasındaki iliski. Yayımlanmamış doktora tezi, Abant İzzet Baysal Üniversitesi, Egitim Bilimleri Enstitüsü, Bolu.

Fettahlığlu, Ö. O. ve Sayın, Z. F. (2015). Örgütsel sapma ve örgütsel güven davranışları arası ilişkilere yönelik alan araştırması. Journal of Social, Humanities and Administrative Sciences Open Access Refereed E-Journal, 1(1), 51-65.

Gezen, T. ve Boz, H. (2013). Otel işletmelerinde örgütsel güven ile işten ayrılma niyeti arasındaki ilişkinin incelenmesi. 14. Ulusal Turizm Kongresi 2013, 891-907.

Gibb, R.J. (1991). Trust: A new vision of human relationships for business, education, family, and personal living. (Second Edition). California: Newcastle Publishing. 
Gökduman, D. (2012). İlköğretim okulu öğretmenlerinin örgütsel güven algılarının bazı değişkenler açısından incelenmesi. Yayımlanmamış yüksek lisans tezi, Ahi Evran Üniversitesi, Kırşehir.

Gören, S. Ç. ve Özdemir, M. (2015). Ortaokul öğretmenlerinin örgütsel güvene ilişkin görüşlerinin bazı değişkenlere göre incelenmesi. Mersin Üniversitesi Eğitim Fakültesi Dergisi, 11(3), 793-801.

Güler, S. (2014). Örgütlerde güven algılamasının örgütsel sinizm üzerine etkisi ve bir araştırma. Yayımlanmamış yüksek lisans tezi, Pamukkale Üniversitesi, Denizli.

Güneş, D. Z. (2014). Illköğretim okulu öğretmenlerinin örgütsel güven ve kolektif yeterlikleri algıları ile örgütsel farkındalık düzeyleri arasındaki ilişkilerin incelenmesi. Yayınlanmamış doktora tezi, Abant İzzet Baysal Üniversitesi, Bolu.

Halıcı, M., Söyük, S. ve Gün, İ. (2015). Sağlık çalışanlarında örgütsel güven. Yönetim ve Ekonomi Araştırmaları Dergisi, 13(3), 180-198.

Halis, M., Gökgöz, G. S. ve Yaşar, Ö. (2007). Örgütsel güvenin belirleyici faktörleri ve bankacilık sektöründe bir uygulama. Manas Üniversitesi Sosyal Bilimler Dergisi, 17, 187205.

Hoy, W. K., \& Tarter, C. J. (2004). Organizational justice in schools: No justice without trust. International Journal of Educational Management, 4, 205-259.

Hodge, E. M. \& Ozağ, D. (2007). The relationship between North Carolina teachers' trust and hope and their organizational commitment. Delta Pi Epsilon Journal, 49(2), 128-139.

Hosmer, L. T. (1995). Trust: The connecting link between organizational theory and philosphical ethics. Academy of Management Review, 20, 379-403.

İbrahimoğlu, N.; Yaşar, Ö. ve Kızıloğlu, U. M. (2011). Örgütlerde mentorlügüun örgütsel güven algısına etkisine ilişkin bir araştırma. Çukurova Üniversitesi Sosyal Bilimler Enstitüsü Dergisi, 20(3), 297-318.

İnam, A. (2003). Her şeyin başı güven. (Ed.) F. Erdem. Sosyal bilimlerde güven içinde. Ankara: Vadi Yayınları.

İşcan, Ö. F. ve Sayın, U. (2010). Örgütsel adalet, iş tatmini ve örgütsel güven arasındaki ilişki. Atatürk Üniversitesi İktisadi ve İdari Bilimler Dergisi, 24(4), 195-216.

Kalemci Tüzün, İ. (2007). Güven, örgütsel güven ve örgütsel güven modelleri. Karamanoğlu Mehmetbey Üniversitesi Sosyal ve Ekonomik Araştırmalar Dergisi, 2, 93-118.

Karaçay-Sevik, M. (2012). Illköğretim okulları müdürlerinin liderlik stilleri ile öğretmenlerin örgütsel güven algıları arasındaki ilişki. Yayımlanmamış yüksek lisans tezi, Maltepe Üniversitesi, Sosyal Bilimler Enstitüsü, İstanbul.

Karasar, N. (2003). Bilimsel araştırma yöntemi. Ankara: Nobel Yayın Dağıtım.

Kars, M. ve İnand1, Y. (2018). Relationship between school principals' leadership behaviors and teachers' organizational trust. Eurasian Journal of Educational Research, 74, 145-164.

Korkmaz, O. (2017). Otantik liderlik ve örgütsel güven. The Journal of Academic Social Science Studies, 58, 437-454. 
Kovanc1, M. (2020). Öğretmenlerin örgütsel güven algılarının örgütsel yabancılaşma davranışları ile ilişkisi. Dünya Multidisipliner Araştırmalar Dergisi, 2020(1), 96-124.

Mayer, R. C. Davis J. H., Schoorman, D. F. (1995). An integrative model of organizational trust. Academy of Management Review, 20(3), 709-734.

Özdil, K. (2005). İlköğretim okullarında öğretmenlerin yöneticilerine ve birbirlerine duyduklarn güven düzeyi ile örgütsel iklimi arasındaki ilişki (Yeni Mahalle Örneği). Yayınlanmamış doktora tezi, Hacettepe Üniversitesi, Sosyal Bilimler Enstitüsü, Ankara.

Özer, N., \& Akbaş, M. (2016). Ortaokul öğretmenlerinin okul kültürü profili ve örgütsel güvene ilişkin algıları arasındaki ilişki. Milli Ĕ̆itim Dergisi, 45(211), 63-86.

Özgan, H. (2011). Örgütsel davranış bağlamında öğretmenlerin örgütsel adalet, güven, bağl1lık, yönetici değerlendirme ve çatışma yönetimi stratejileri algıları arasındaki ilişkilerin incelenmesi. Kuram ve Uygulamada Ĕ̆itim Bilimleri Dergisi, 11(1), 229- 247.

Öztürk, Ç. (2011). Ortaöğretim okulu öğretmenlerinin örgütsel güven algıları. Gaziantep Üniversitesi Sosyal Bilimler Dergisi, 11(2), 485- 504.

Paşa, Ö. ve Işık, A.N. (2017). Öğretmenlerin okul müdürüne güven düzeyleri ve okul müdürü tarafından sergilenen etik liderlik davranışlarının örgütsel sessizlik üzerindeki etkisi. Elektronik Sosyal Bilimler Dergisi, 16(60), 134-144.

Polat, S. (2007). Ortä̈ğretim öğretmenlerinin örgütsel adalet algılar, örgütsel güven düzeyleri ile örgütsel vatandaşlık davranışları arasındaki ilişki. Yayımlanmamış doktora tezi, Kocaeli Üniversitesi Sosyal Bilimler Enstitüsü, Kocaeli.

Polat, S., \& Celep, C. (2008). Ortaöğretim öğretmenlerinin örgütsel adalet, örgütsel güven, örgütsel vatandaşlık davranışlarına ilişkin algıları. Kuram ve Uygulamada Eğitim Yönetimi, 54(54), 307-331.

Polat, S. (2009). Eğitim örgütleri için sosyal sermaye: Örgütsel güven. Ankara: Pegem A Yayıncllı.

Seçilmiş C. ve Kılıç İ. (2017). Örgütsel güven, iş-aile yaşam çatışması ve işten ayrılma niyeti ilişkisinin belirlenmesi: Seyahat acentelerinde bir uygulama. Turizm Akademik Dergisi, $4(1), 65-79$.

Sipahioğlu, M. ve Öner, M. (2013). Ortaöğretim kurumlarında çalışan öğretmenlerin örgütsel güven algıları. Ĕğitim ve Öğretim Araştırmaları Dergisi, 2(3), 104-111.

Smith, P. A., \& Birney, L. L. (2005). The organizational trust of elementary schools and dimensions of student bullying. International Journal of Educational Management, 19(6), 469-485.

Tan, H ve C.S. Tan (2000). Towards the differentiation of trust in supervisor and trust in organization. Genetic, Social and General Psychology Monographs, 126(2), 241-260.

Tasdan, K. (2012). Turkish primary school teachers' perceptions of organizational trust. New Educational Review, 30(4), 176-190.

Thomas, G.F.; Zolin, R. ve Hartman, J.L. (2009). The central role of communication in developing trust and its effect on employee involvement. Journal of Business Communication, 46(3), 287-310. 
Tschannen-Moran, M., \& Hoy, W. K. (2000). A multidisciplinary analysis of the nature, meaning, and measurement of trust. Review of educational research, 70(4), 547-593.

Uysal, E. (2014). Lise öğretmenlerinin örgütsel güven algıları ile örgütsel bağlllık düzeyleri arasındaki ilişki. Yayımlanmamış yüksek lisans tezi, Gazi Üniversitesi, Ankara.

Van Maele, D. ve Van Houtte, M. (2015). Trust in school: A pathway to inhibit teacher burnout? Journal of Educational Administration, 53(1), 93-115.

Yıldız, K. (2013). Öğretmenlerin örgütsel adalet ve örgütsel güven algıları. Abant İzzet Baysal Üniversitesi Sosyal Bilimler Enstitüsü Dergisi, 13(1), 289-316.

Yılmaz, E. (2006). Okullardaki örgütsel güven düzeyinin okul yöneticilerinin etik liderlik özellikleri ve bazı değişkenler açısından incelenmesi. Yayımlanmamış doktora tezi, Selçuk Üniversitesi Sosyal Bilimler Enstitüsü, Konya.

Yılmaz, K. (2006). Güven ölçeği'nin geçerlik ve güvenirlik çalışması. Sakarya Üniversitesi Eğitim Fakültesi Dergisi, 11, 69-80.

Yılmaz, K. (2009). Özel dershane öğretmenlerinin örgütsel güven düzeyleri ile örgütsel vatandaşlık davranışları arasındaki ilişki. Kuram ve Uygulamada Eğitim Yönetimi, 59(59), 471-490.

Yücel, C. ve Samancı, G. (2009). Örgütsel güven ve örgütsel vatandaşlık davranışı. Fırat Üniversitesi Sosyal Bilimler Dergisi, 19(1), 113-132. 